\title{
UMA POSSIBILIDADE DE APRENDER CRITICAMENTE O CONHECIMENTO CIENTÍFICO
}

\author{
Edena Carla Dorne Cavalli* $\quad$ Ivania Guerni Camargo \\ Projeto de Formação Continuada para Professores da Educação Básica nos Anos Iniciais \\ UNIOESTE - PR \\ E-mail: ed-cavalli@uol.com.br \\ E-mail: Ivania_guerini@homail com
}

\begin{abstract}
RESUMO
O presente trabalho tem o objetivo de refletir sobre a prática pedagógica diária, a partir de leituras, estudos e reflexões acerca de uma nova proposição didática, respaldada na teoria dialética do conhecimento e sua aplicação na elaboração de planos de aulas de Matemática nas séries iniciais do Ensino Fundamental e execução na sala de aula. O trabalho foi realizado com Professores da Rede Municipal de Ensino da região Oeste do Paraná e faz parte do Projeto de Pesquisa e Extensão Formação Continuada para Professores da Educação Básica nos anos iniciais: ações voltadas para a Alfabetização em Municípios com Baixo IDEB da Região Oeste do Paraná, do Programa de Pós-graduação Stricto Sensu em Letras - Nível Mestrado, com área de concentração em Linguagem e Sociedade, que atendeu ao Edital 038/2010 - CAPES/INEP do Observatório da Educação.

Diante das dificuldades, muitas vezes, encontradas pelos professores em realizar um trabalho em sala de aula que ultrapasse a mera transmissão dos conteúdos, somado ao fato de que a metodologia utilizada contribui para o sucesso ou o fracasso do aluno, é que se justificam algumas ações, a partir de uma Oficina pedagógica, voltadas aos professores dos anos iniciais a respeito de uma proposta pedagógica, que se fundamenta numa concepção metodológica dialética do conhecimento, com base na Pedagogia Histórico-crítica, a qual possibilita que o educando compreenda a essência dos conteúdos e estabeleça uma relação destes com sua realidade. Na concepção dialética, "a prática social, põe-se, portanto como ponto de partida e chegada da prática educativa" (SAVIANI, 2007, p. 420).

Esta teoria embasa um novo método de trabalho, a qual é marcada pela teoria dialética do conhecimento, ou seja, parte da realidade social como um todo para a especificidade teórica da sala de aula e desta para a totalidade social novamente, proporcionando um rico processo dialético de trabalho pedagógico. (GASPARIN, 2003). O Grupo de estudo foi fundamentado neste método, esta proposta é dividida em cinco passos que contribuem para o desenvolvimento do aluno, foi estruturada por Gasparin (2003) sendo eles: A Prática Social Inicial, caracterizada como uma preparação do aluno para a construção dos conhecimentos escolares; a Problematização, que objetiva selecionar e discutir problemas que tem sua origem na prática social, a qual é ligada ao conteúdo, consistindo num processo de relação entre os saberes; a Instrumentalização, que é o caminho pelo qual o conteúdo sistematizado é posto á disposição do aluno para que estes o assimile, recrie, incorpore e transforme-o em instrumento de construção tanto pessoal quanto profissional; a Catarse, que consiste na síntese do cotidiano científico, do teórico e do prático, no qual o aluno chegou, expresso através da nova posição do aluno em relação ao conteúdo e reconstrução na escola e por fim a Prática Social Final, que é o novo agir do aluno, a partir da relação da prática com a teoria.
\end{abstract}

* Membro do Projeto de Formação Continuada para Professores da Educação Básica Anos Iniciais - UNIOESTE - PR. 


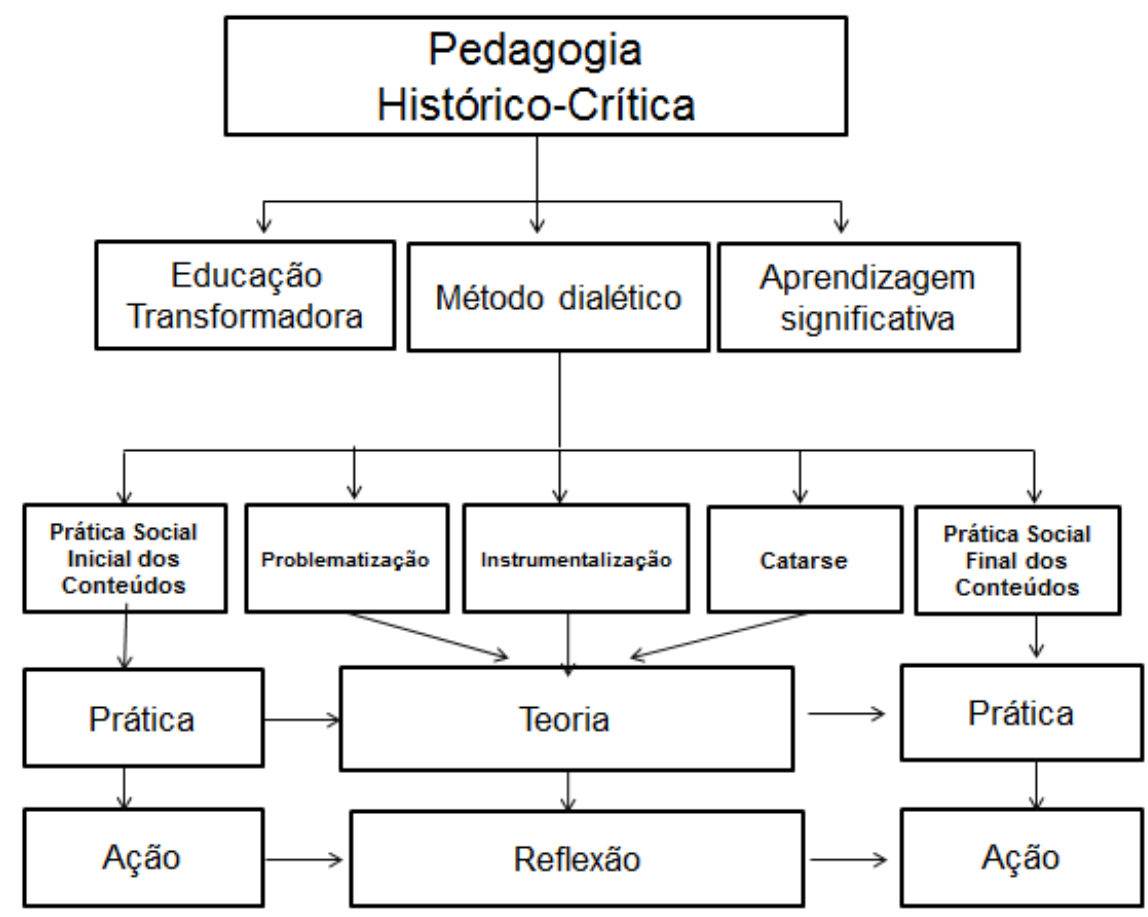

Após estudo, os professores elaboraram aulas de Matemática seguindo o passo a passo desta proposta pedagógica e socializaram entre os participantes do grupo de estudo para então, aplicarem em sala de aula.

Palavras chaves: Formação Continuada, Pedagogia Histórico Critica e Método Dialético.

\section{REFERÊNCIAS}

[1] GASPARIN, J.L. Uma didática para a pedagogia histórico-crítica. 2. Ed. Campinas, SP: Autores Associados, 2003.

[2] SAVIANI, D. História das ideias pedagógicas no Brasil. São Paulo: Autores Associados, 2007. 